\title{
Protocol: methodology for chromatin immunoprecipitation (ChIP) in Chlamydomonas reinhardtii
}

\author{
Daniela Strenkert, Stefan Schmollinger and Michael Schroda*
}

\begin{abstract}
We report on a detailed chromatin immunoprecipitation (ChIP) protocol for the unicellular green alga Chlamydomonas reinhardtii. The protocol is suitable for the analysis of nucleosome occupancy, histone modifications and transcription factor binding sites at the level of mononucleosomes for targeted and genomewide studies. We describe the optimization of conditions for crosslinking, chromatin fragmentation and antibody titer determination and provide recommendations and an example for the normalization of ChIP results as determined by real-time PCR.
\end{abstract}

Keywords: Chromatin immunoprecipitation, Chlamydomonas reinhardtii, heat shock, formaldehyde crosslinking, real-time PCR, nucleosome occupancy, histone modification, HSP7OA, RBCS2, CYC6

\section{Background}

Since several decades the unicellular green alga Chlamydomonas reinhardtii serves as a model organism for studying various aspects of cell biology [1]. However, although all three genetic compartments have been sequenced and are amenable for genetic manipulation [2], transgenic approaches frequently suffer from low transgene expression levels and from transgene silencing [3]. Recent work has shown that this is largely due to epigenetic mechanisms that frequently involve histone modifications. Several factors mediating histone modifications have already been identified in Chlamydomonas, mainly by Cerutti and coworkers: one of them is MUT11, a WD40-repeat protein homologous to human WDR5. Deletion of MUT11 resulted in the activation of single-copy transgenes and of dispersed transposons [4]. MUT11 was shown to interact with SET domain histone methyltransferases and suppression of SET1 by RNAi came along with a reduction in levels of monomethylated $\mathrm{H} 3 \mathrm{~K} 4$, an epigenetic mark associated with transcriptionally repressed loci [5]. Another factor is the SU (VAR)3-9-related protein SET3p. RNAi-mediated suppression of SET3 released the transcriptional silencing

\footnotetext{
*Correspondence: Schroda@mpimp-golm.mpg.de
Max-Planck-Institut für Molekulare Pflanzenphysiologie, Am Mühlenberg 1, D-

*Correspondence: Schroda@mpimp-golm.mpg.de
Max-Planck-Institut für Molekulare Pflanzenphysiologie, Am Mühlenberg 1, D14476 Potsdam-Golm, Germany
}

of tandemly repeated transgenes and correlated with a partial loss of monomethyl H3K9 at such loci [6]. Again another factor is the MUT9p kinase which phosphorylates $\mathrm{H} 3 \mathrm{~T} 3$ and histone $\mathrm{H} 2 \mathrm{~A}$ and is required for longterm, heritable gene silencing [7]. Furthermore, the Chlamydomonas enhancer of zeste homolog (EZH) catalyzes H3K27 methylation. RNAi-mediated suppression of EZH in Chlamydomonas resulted in a global increase in levels of histone H3K4 trimethylation and $\mathrm{H} 4$ acetylation, two characteristic marks for active chromatin, thereby leading to the release of retrotransposons and of silenced, tandemly repeated transgenes [8]. Finally, Yamasaki and coworkers found that silencing of a transgenic $R B C S 2$ promoter, driving the expression of an inverted repeat construct, was associated with low levels of histone $\mathrm{H} 3$ acetylation and high levels of monomethylated H3K9 at the transgenic promoter [9]. Deletion of the Elongin $C$ gene, which is a component of some E3 ubiquitin ligase complexes, released silencing of the transgenic RBCS2 promoter. The activated promoter was characterized by high levels of $\mathrm{H} 3$ acetylation and low levels of H3K9 monomethylation [10]. These data clearly show that Chlamydomonas is an excellent model organism for studying the epigenetic mechanisms underlying gene silencing. 
In the past Chlamydomonas also served as a valuable model organism for identifying key transcription factors that regulate responses to various stress conditions, like the copper response regulator (CRR1) [11], the regulator of the phosphorus starvation response (PSR1) [12], the regulator of the carbon concentrating mechanism (CCM1/CIA5) $[13,14]$ or the regulator of the heat shock response (HSF1) [15]. How these transcription factors regulate the expression of their target genes at the level of chromatin structure is poorly understood and only recently has become subject of investigation in our laboratory [16]. Our results revealed that CRR1 and HSF1 regulate the expression of their target genes via histone acetylation, histone methylation, nucleosome eviction and polymerase loading/activation. At each target promoter these means are employed individually to establish a characteristic chromatin state allowing for a fine-tuning of gene expression [16].

The ideal tool to study the mechanisms underlying transgene silencing and gene expression at the level of chromatin structure is chromatin immunoprecipitation (ChIP), a method that was first introduced for Drosophila [17] and has since then enormously gained in popularity. The first step in the ChIP protocol is the "freezing" of the chromatin state by infiltrating cells with formaldehyde to crosslink DNA-binding proteins with DNA. After mechanical shearing of the DNA the protein of interest is immunoprecipitated with specific antibodies together with the DNA it is binding to. The crosslinks can be reversed and the precipitated DNA is subjected to PCR for the analysis of specific loci, or to microarray hybridization/deep sequencing for the genome-wide analysis of binding sites of the protein of interest. The latter techniques have allowed for the establishment of genome-wide maps of histone modifications [18] and transcription factor binding sites [19].

Detailed ChIP protocols are published for Tetrahymena thermophila [20], Drosophila [21], yeast [22], mammalian cell lines [23], and more recently also for higher plants like Arabidopsis [24], maize [25] and tomato [26]. Although ChIP has been applied to Chlamydomonas previously $[5-7,9,10,16,27]$, a thorough documentation of important parameters and a step-by-step protocol are yet missing, which to provide is the goal of this work.

\section{Materials and methods}

Chlamydomonas strains and cultivation conditions

Chlamydomonas reinhardtii strains were grown mixotrophically in Tris-acetate-phosphate (TAP) medium [1] on a rotary shaker at $24^{\circ} \mathrm{C}$ and $\sim 30 \mu \mathrm{E} \mathrm{m} \mathrm{sec}^{-1}$. Used were cell wall deficient strains CF185 [28] and 325-412 (arg7 strain 325 transformed with pCB412 containing the wild-type $A R G 7$ gene [16]) and cell walled strain CRR16 (crr1'/arg7 strain CC3960 co-transformed with plasmids pARG7.8 and pCRR1F1B6 [11]). For heat shock experiments, cells were pelleted by a 4-min centrifugation at $24^{\circ} \mathrm{C}$ and $2704 \times$ g, resuspended in TAP medium prewarmed to $40^{\circ} \mathrm{C}$ and incubated under agitation in a water bath at $40^{\circ} \mathrm{C}$. Prior to harvest, ice was added to the cells.

\section{DNA fragmentation}

A BANDELIN Sonopuls Sonifier HD 2070 with sonication tip MS 73 was used to shear DNA by sonication.

\section{Antibodies}

Antibodies against the unmodified C-terminus of histone H3 were purchased from Abcam (ab1791). Antibodies against diacetyl H3K9/K14 and tetra-acetyl H4K5/ K8/K12/K16 were from Upstate (06-599 and 06-866, respectively). Antibodies against VIPP2 (mock control) were affinity-purified as described previously [29].

\section{Buffers \\ KH buffer}

$20 \mathrm{mM}$ Hepes-KOH pH 7.6

$80 \mathrm{mM} \mathrm{KCl}$

\section{Crosslinking solution}

20 mM Hepes-KOH pH 7.6

$80 \mathrm{mM} \mathrm{KCl}$

0.35\% formaldehyde (Roth, ROTIPURAN p.a., 4979.1)

(as formaldehyde decays easily it is important to use fresh stocks; also always prepare the crosslinking solution freshly)

\section{Lysis buffer}

1\% SDS

$10 \mathrm{mM}$ EDTA

$50 \mathrm{mM}$ Tris- $\mathrm{HCl}(\mathrm{pH} 8.0)$

$0.25 \times$ protease inhibitor cocktail (Roche, complete, EDTA-free, 11873580001)

Washing buffer 1 (low salt) $150 \mathrm{mM} \mathrm{NaCl}$

$0.1 \%$ SDS

1\% Triton X-100

2 mM EDTA (pH 8.0)

Washing buffer 2 (high salt)

$500 \mathrm{mM} \mathrm{NaCl}$

$0.1 \%$ SDS

1\% Triton $\mathrm{X}-100$

2 mM EDTA (pH 8.0)

Washing buffer 3 (LiCl)

$250 \mathrm{mM} \mathrm{LiCl}$ 
1\% Nonidet P40 (Roche, 1754599)

1\% Na-deoxycholate (Fluka, > 98.0\%, 30970)

1 mM EDTA (pH 8.0)

$10 \mathrm{mM}$ Tris- $\mathrm{HCl}(\mathrm{pH} 8.0)$

\section{TE buffer}

$10 \mathrm{mM}$ Tris- $\mathrm{HCl}(\mathrm{pH} \mathrm{8.0)}$

1 mM EDTA (pH 8.0)

\section{ChIP buffer}

1.1\% Triton X-100

1.2 mM EDTA

$167 \mathrm{mM} \mathrm{NaCl}$

16.7 mM Tris-HCl (pH 8.0)

\section{Lysis buffer}

$1 \%$ SDS

10 mM EDTA

$50 \mathrm{mM}$ Tris- $\mathrm{HCl}(\mathrm{pH} 8.0)$

\section{Elution buffer}

$1 \%$ SDS

$\mathrm{M} \mathrm{NaHCO} 3$ (prepare freshly)

\section{Stock solutions}

${ }$ DNA $_{\text {soni }}: 100 \mu \mathrm{g} / \mathrm{ml}$ (Fermentas, \#SD0011, in ChIP-buffer) [sonicated 4 times $10 \mathrm{sec}$, output control: $55 \%$; duty cycle: $60 \%$ ]

BSA: $10 \mathrm{mg} / \mathrm{ml}$ (Sigma, A4503, in $\lambda \mathrm{DNA}_{\text {soni }}$ ) Glycogen: $2.5 \mu \mathrm{g} / \mu \mathrm{l}$ (Roth, HP51.2, in ChIP-buffer)

Glycine: $1 \mathrm{M}$

Phenol/chloroform/isoamylalcohol (25:24:1)

Chloroform/isoamylalcohol (24:1)

TE buffer containing $20 \mu \mathrm{g} / \mu \mathrm{l}$ boiled RNase A

Proteinase K: $10 \mathrm{mg} / \mathrm{ml}$ (Roth, lyophil. > $30 \mathrm{U} / \mathrm{mg}$, 7523.3)

Na-acetate: 3 M (pH 5.2, adjusted with acetic acid) NaCl: $5 \mathrm{M}$

2x DNA loading dye: $15 \%$ Ficoll- 400

EDTA: $5 \mathrm{M}(\mathrm{pH}$ 8.0)

Tris-HCl: $1 \mathrm{M}(\mathrm{pH} 8.0)$

\section{Protocol}

\section{Cell harvest and crosslinking}

1. Grow Chlamydomonas cells in $400 \mathrm{ml}$ TAP medium to a density of 4-8 $\times 10^{6} \mathrm{cells} / \mathrm{ml}$.

2. Harvest $10^{9}$ cells in GSA tubes by centrifuging for 3 min at $3220 \times \mathrm{g}$ and $24^{\circ} \mathrm{C}$ [ $4^{\circ} \mathrm{C}$ if cells are not subjected to further treatments].

3. [For heat shock, resuspend cells in $45 \mathrm{ml}$ TAP medium prewarmed to $40^{\circ} \mathrm{C}$ and incubate in a $40^{\circ} \mathrm{C}$ water bath. Transfer cells into a $50-\mathrm{ml}$ Falcon tube containing crushed ice and centrifuge for $3 \mathrm{~min}$ at $3220 \times \mathrm{g}$ and $4^{\circ}$ C].

4. Discard supernatant and resuspend cells.

5. Add $10 \mathrm{ml}$ of Crosslinking solution, mix gently for $10 \mathrm{~min}$ at $24^{\circ} \mathrm{C}$ (formaldehyde crosslinking).

6. Add $1.25 \mathrm{ml}$ of $1 \mathrm{M}$ glycine, agitate for $5 \mathrm{~min}$ at $24^{\circ}$ $\mathrm{C}$ (quenching).

7. Centrifuge for $2 \mathrm{~min}$ at $3220 \times \mathrm{g}$ and $4^{\circ} \mathrm{C}$, discard supernatant.

8. Resuspend cells in $1 \mathrm{ml} \mathrm{KH}$ buffer and transfer them into a 2-ml microcentrifuge tube.

9. Centrifuge for $2 \mathrm{~min}$ at $16,100 \times \mathrm{g}$ and $4^{\circ} \mathrm{C}$, discard supernatant.

10. Add $400 \mu \mathrm{l}$ Lysis buffer; after this step cells can be stored at $-80^{\circ} \mathrm{C}$ for several months.

\section{Cell lysis and fragmentation of DNA}

[In case strains with cell wall are used it is essential to add an additional $500 \mu \mathrm{l}$ of Lysis buffer. Vortex briefly and transfer cell lysate to Ultra-Clear Centrifuge Tubes $(1 / 2 \times 2$ in. $(13 \times 51 \mathrm{~mm})$, Beckman). Cell wall-deficient strains can be further processed in 2-ml microcentrifuge tubes].

11. Sonicate on ice with $55 \%$ output control, $60 \%$ duty cycle. To achieve an average DNA fragment size of $\sim 200 \mathrm{bp}$, sonicate 20 times $20 \mathrm{sec}$ with breaks of $20 \mathrm{sec}$ between each sonication cycle (avoid frothing!). The sonicator tip needs to be as close as possible to the bottom of the tube.

\section{Aliquot samples}

12. Transfer sonicated cell lysates to $15-\mathrm{ml}$ Falcon tubes, add Lysis buffer to a total volume of $5 \mathrm{ml}$ and mix carefully.

13. Centrifuge for $2 \mathrm{~min}$ at $3220 \times \mathrm{g}$ and $4^{\circ} \mathrm{C}$ to remove cell debris.

14. Aliquot $50 \times 100 \mu \mathrm{l}(100-\mu \mathrm{l}$ aliquots correspond to chromatin from $\sim 2 \times 10^{7}$ cells). The input chromatin can be stored for several months at $-80^{\circ} \mathrm{C}$, but avoid multiple freeze/thaw cycles.

(In contrast to long-term storage, repeated freezethawing cycles lead to protein degradation [30]).

\section{Quality control of sheared DNA}

15. Take one 100- $\mu \mathrm{l}$ aliquot and add $400 \mu \mathrm{l}$ of Lysis buffer and $50 \mu \mathrm{l}$ of $5 \mathrm{M} \mathrm{NaCl}$.

16. Incubate over night at $65^{\circ} \mathrm{C}$ to reverse crosslinks.

17. Extract twice with $500 \mu \mathrm{l}$ phenol/chloroform/ isoamylalcohol.

18. Extract once with $500 \mu \mathrm{l}$ chloroform/ isoamylalcohol.

19. Precipitate nucleic acids by adding $55 \mu \mathrm{l}$ of $3 \mathrm{M}$ $\mathrm{Na}$-acetate (pH 5.2), $1 \mathrm{ml}$ of $100 \% \mathrm{EtOH}$ and incubating for $3 \mathrm{~h}$ at $-20^{\circ} \mathrm{C}$.

20. Centrifuge for $15 \mathrm{~min}$ at $16,100 \times \mathrm{g}$ and $4^{\circ} \mathrm{C}$. 
21. Wash pellet with $800 \mu \mathrm{l}$ of $70 \% \mathrm{EtOH}$ (take care not to remove the tiny pellet).

22. Centrifuge for $10 \mathrm{~min}$ at $16,100 \times \mathrm{g}$ and $4{ }^{\circ} \mathrm{C}$.

23. Dry pellet and resuspend it in $10 \mu \mathrm{l}$ TE buffer containing $20 \mu \mathrm{g} / \mu \mathrm{l}$ RNase A.

24. Incubate for $1 \mathrm{~h}$ at $37^{\circ} \mathrm{C}$.

25. Add $10 \mu \mathrm{l}$ of $2 \times$ DNA loading dye and separate sheared DNA on a $1.5 \%$ agarose gel. DNA fragments should have sizes of $\sim 200 \mathrm{bp}$.

\section{Preparation of Protein A-Sepharose beads}

26. Weigh-in $50 \mathrm{mg}$ of Protein-A-Sepharose beads (Sigma, P3391-1G), resuspend beads in $1 \mathrm{ml}$ ChIP-buffer and incubate them for $30 \mathrm{~min}$ at $4^{\circ} \mathrm{C}$.

27. Wash beads two times with $500 \mu \mathrm{l}$ ChIP buffer

28. Discard supernatant and add $250 \mu \mathrm{l}$ ChIP-buffer and $250 \mu \mathrm{l} \lambda \mathrm{DNA}_{\text {soni }}$ (gives $\sim 750 \mu \mathrm{l}$ suspension with swollen beads).

\section{Chromatin-Immunoprecipitation}

29. Prepare antibody solutions (for example, mix $5 \mu \mathrm{l}$ of anti-H3 antibodies with $10 \mu \mathrm{l}$ BSA in $\lambda \mathrm{DNA}_{\text {soni }}$ solution and incubate for at least $30 \mathrm{~min}$ on ice).

30. For each antibody employed, thaw one 100- $\mu \mathrm{l}$ aliquot of chromatin solution on ice (for each strain/ condition we also recommend a control without antibody).

31. Add $900 \mu \mathrm{l}$ of ChIP buffer to each aliquot (from this step on consequently use stuffed tips to avoid DNA contaminations!).

32. Centrifuge for $20 \mathrm{sec}$ at $16,100 \times \mathrm{g}$ and $4{ }^{\circ} \mathrm{C}$, and transfer supernatant to microcentrifuge tubes containing the prepared antibody solutions.

33. Mix on a rotation wheel for $1 \mathrm{~h}$ at $4^{\circ} \mathrm{C}$.

34. Centrifuge for $20 \mathrm{sec}$ at $16,100 \times \mathrm{g}$ and $4^{\circ} \mathrm{C}$, and transfer each supernatant to microcentrifuge tubes containing $60 \mu \mathrm{l}$ sepharose beads.

35. Mix on a rotation wheel for $2 \mathrm{~h}$ at $4^{\circ} \mathrm{C}$.

36. Centrifuge for $20 \mathrm{sec}$ at $16,100 \times \mathrm{g}$ and $4^{\circ} \mathrm{C}$.

37. Discard supernatant.

38. Wash the beads once with $1 \mathrm{ml}$ each of Washing buffer 1, 2 and 3, and twice with $1 \mathrm{ml}$ TE buffer (use washing solutions that are stored on ice and centrifuge at $\left.4^{\circ} \mathrm{C}\right)$.

\section{Elution}

39. Elute precipitated chromatin with $250 \mu$ l Elution buffer for $15 \mathrm{~min}$ at $65^{\circ} \mathrm{C}$.

40. Repeat elution with another $250 \mu$ Elution buffer and pool eluates.

\section{Reversion of the crosslink}

41. Add $50 \mu \mathrm{l}$ of $5 \mathrm{M} \mathrm{NaCl}$ and incubate overnight at $65^{\circ} \mathrm{C}$.

42. To remove proteins in the precipitates add $10 \mu \mathrm{l}$ $0.5 \mathrm{M}$ EDTA ( $\mathrm{pH} 8.0), 20 \mu \mathrm{l} 1 \mathrm{M}$ Tris-HCl ( $\mathrm{pH}$ 8.0) and $2.1 \mu \mathrm{l}$ proteinase $\mathrm{K}(10 \mathrm{mg} / \mathrm{ml})$ and incubate for $1 \mathrm{~h}$ at $55^{\circ} \mathrm{C}$.

\section{DNA extraction}

43. Extract once with $500 \mu \mathrm{l}$ phenol/chloroform/ isoamylalcohol.

44. Extract once with $500 \mu \mathrm{l}$ chloroform/ isoamylalcohol.

45. Precipitate DNA by adding $50 \mu \mathrm{l} 3 \mathrm{M} \mathrm{Na}$-acetate (pH 5.2), $2.5 \mu \mathrm{l}$ glycogen $(2.5 \mu \mathrm{g} / \mu \mathrm{l})$ and $1 \mathrm{ml} 100 \%$ $\mathrm{EtOH}$ and incubating for $3 \mathrm{~h}$ at $-20^{\circ} \mathrm{C}$.

46. Centrifuge for $20 \mathrm{~min}$ at $16,100 \times \mathrm{g}$ and $4^{\circ} \mathrm{C}$.

47. Wash DNA pellet with $500 \mu \mathrm{l} 70 \% \mathrm{EtOH}$ (take care not to remove the tiny pellet).

48. Centrifuge for $15 \mathrm{~min}$ at $16,100 \mathrm{~g}$ and $4^{\circ} \mathrm{C}$.

49. Dry DNA pellet in a clean bench, resuspend in 200 $\mu \mathrm{TE}(\mathrm{pH} 8.0)$.

50. Use $5 \mu \mathrm{l}(1: 40)$ of the precipitate for qPCR analysis (if each analysis is done with 3 technical replicates the precipitate is sufficient for 13 targets).

\section{Endpoint PCR}

Endpoint PCRs were carried out in 50- $\mu$ l reactions containing $1 \times$ Taq buffer (Fermentas), $5 \mu$ l chromatin immunoprecipitate, $1.5 \mathrm{mM} \mathrm{MgCl} 2,1 \mathrm{M}$ betaine, 200 $\mu \mathrm{M}$ dNTPs, $2.5 \mathrm{U}$ Taq polymerase (NEB), and $0.6 \mu \mathrm{M}$ each of forward and reverse primers (see Table 1). The reaction conditions were as follows: $95^{\circ} \mathrm{C}$ for $5 \mathrm{~min}$, followed by 27 cycles of $94^{\circ} \mathrm{C}$ for $1 \mathrm{~min}, 68^{\circ} \mathrm{C}$ for $1 \mathrm{~min}$ and $74^{\circ} \mathrm{C}$ for $30 \mathrm{sec}$. An extension step at $74^{\circ} \mathrm{C}$ for 5 min was added. (Note that endpoint PCR is not an advisable method for the analysis of ChIP results as the cycle number needs to be tested empirically with dilution series until product signals are in the linear range).

$q P C R$

qPCR was performed using the StepOnePlus System (Applied Biosystems) and the Maxima SYBR Green kit from Fermentas. Each reaction contained the vendor's master mix, $200 \mathrm{nM}$ of each primer (see Table 1), and 5

Table 1 Primers used in this study

\begin{tabular}{|c|c|c|c|}
\hline Nr. & Target & Primer sequences $\left(5^{\prime}\right.$ to $\left.3^{\prime}\right)$ & $\begin{array}{l}\text { Amplicon size } \\
\text { (bp) }\end{array}$ \\
\hline 1 & $\begin{array}{l}\text { HSP70A } \\
\text { promoter } \\
\text { (endpoint } \\
\text { PCR) }\end{array}$ & $\begin{array}{l}\text { For: } \\
\text { GACGGTGGGGAGCTCGCTGAGGC } \\
\text { Rev: } \\
\text { GGTGCCCAGGTCAATACCGATAGC }\end{array}$ & 327 \\
\hline 2 & $\begin{array}{l}\text { RBCS2 } \\
\text { promoter } \\
\text { (endpoint } \\
\text { PCR) }\end{array}$ & $\begin{array}{l}\text { For: } \\
\text { GCCAGAAGGAGCGCAGCCAAACCA } \\
\text { Rev: } \\
\text { ACGGAGGACTTGGCAATGACGG }\end{array}$ & 237 \\
\hline 3 & $\begin{array}{l}\text { HSP70A } \\
\text { promoter } \\
\text { (qPCR) }\end{array}$ & $\begin{array}{l}\text { For: CGGTATAAAAGCCCGCGAC } \\
\text { Rev: } \\
\text { GTGCCCAGGTCAATACCGATAG }\end{array}$ & 163 \\
\hline 4 & $\begin{array}{l}\text { RBCS2 } \\
\text { promoter } \\
(q P C R)\end{array}$ & $\begin{array}{l}\text { For: CAATGCAAGCAGTTCGCATG } \\
\text { Rev: ACGGAGGACTTGGCAATGAC }\end{array}$ & 138 \\
\hline 5 & $\begin{array}{l}\text { CYC6 } \\
\text { promoter } \\
(q P C R)\end{array}$ & $\begin{array}{l}\text { For: ACACGCCCCTCATTCACAGA } \\
\text { Rev: GCACACGAGACACTCCGAGC }\end{array}$ & 121 \\
\hline
\end{tabular}


$\mu \mathrm{l}$ chromatin precipitate. The reaction conditions were as follows: $95^{\circ} \mathrm{C}$ for $10 \mathrm{~min}$, followed by 40 cycles of $95^{\circ}$ $\mathrm{C}$ for $15 \mathrm{sec}$ and $65^{\circ} \mathrm{C}$ for $60 \mathrm{sec}$. For each target we made sure that melting curves had single peaks and that only one PCR product was visible on 1.5\% agarose gels. Non-template controls were generally included.

\section{Comments}

\section{Crosslinking and reversal}

As pointed out previously, the conditions used for the crosslinking of DNA with proteins are crucial for ChIP analyses and need to be optimized for each individual organism $[21,23,25]$. Important parameters are the amount of input material, the formaldehyde concentration and the crosslinking time. Protocols for higher plants start out from 1-5 g of plant tissue and crosslinking is done for $10-15$ min with $1-3 \%$ formaldehyde [24-26,31]. Protocols for Chlamydomonas start out from $2-4 \times 10^{7}$ cells and crosslinking is done for 5-10 min with $0.75-1 \%$ formaldehyde $[5,9]$. Following crosslinking, chromatin is sheared by sonication to average fragment sizes ranging between 200 and $3000 \mathrm{bp}$ (higher plant protocols) [24-26] and 500-1000 bp (Chlamydomonas protocols) $[5,6,9]$.

To optimize crosslinking conditions for Chlamydomonas, we used as fixed parameters $2 \times 10^{7}$ cells as starting material, a crosslinking time of $10 \mathrm{~min}$, and a DNA fragment size of 1000-3000 bp (20 sonication pulses of $10 \mathrm{sec}$ each; Figure 1A). As a variable parameter, we employed formaldehyde concentrations ranging from 0.1 to $1 \%$. As shown in Figure 1B, DNA of high molecular weight and less DNA fragments in the 1000-3000 bp range were recovered when formaldehyde concentrations of $0.7 \%$ and higher were used. An obvious interpretation for this observation is that at formaldehyde concentrations above $0.7 \%$ chromatin is crosslinked to higher-order structures that resist fragmentation by sonication and from which crosslinks cannot be fully reversed. Decrosslinking is performed by over-night incubation at $65^{\circ} \mathrm{C}$ [21] and represents an essential step, as DNA-protein complexes enter the phenol phase and are removed during phenol extraction. Presumably because of the high protein content in compact, overcrosslinked structures, they tend to be removed during phenol extraction. Similar observations with over-crosslinking at too high formaldehyde concentrations or crosslinking times were also reported by others $[21,23,26]$.

To elucidate how the formaldehyde concentration used for crosslinking affects ChIP efficiency, we used antibodies against the unmodified $\mathrm{C}$-terminus of histone H3 (Figure 1C) to immunoprecipitate DNA crosslinked to histones. Subsequently, precipitated DNA fragments from promoters $H S P 70 A$ and $R B C S 2$ were amplified by endpoint PCR. As shown in Figures 1D and 1E, the largest amounts of promoter DNA were precipitated when chromatin was crosslinked with a formaldehyde concentration of $0.35 \%$. Insufficient crosslinking at lower formaldehyde concentrations and over-crosslinking at higher concentrations both impaired ChIP efficiency.

\section{Fragmentation of DNA for high-resolution ChIP}

In Chlamydomonas, the nucleosome repeat length was determined to have values of 156 and $160 \mathrm{bp}$ at the RBCS2 and HSP70A loci, respectively, whereas a value of $178 \mathrm{bp}$ was detected in bulk chromatin [32]. Hence, a DNA fragment size of 1000-3000 bp, as used above for determining the optimal formaldehyde concentrations for crosslinking (Figure 1), would encompass between 6 and 19 nucleosomes. Fragments of this size are therefore neither suitable for studying nucleosome occupancy and histone modifications at high resolution, nor for precisely determining transcription factor binding sites.

To reduce the size of chromatin fragments as input for ChIP we increased the sonication time to 20 times $20 \mathrm{sec}$. This yielded DNA fragments with an average fragment size of $\sim 200 \mathrm{bp}$, basically corresponding to mononucleosomes (Figure 2) [16]. Note that when using such small chromatin fragments, PCR amplicon sizes should not exceed 120-160 bp. Note also that for cell walled Chlamydomonas strains lysis and chromatin shearing need to be carried out with a larger volume of lysis buffer. This increases the effective SDS concentration to efficiently solubilize the proteinaceous cell wall.

\section{Titration of antibodies}

ChIP needs to be performed either under conditions where the investigated epitope is in large excess (e.g. when nucleosome occupancy or abundant histone modifications are analyzed), or where the antibodies used are in large excess (e.g. when transcription factors or rare histone modifications are investigated). In the former case there should be a linear relationship between the amount of antibodies applied and antigen precipitated. In the latter case the amount of antigen precipitated under the respective condition should be constant and independent of the amount of antibodies used. To ensure that these premises are fulfilled it is important to titrate the antibodies used. Titration is also advisable to reduce costs, as commercially available antibodies against histones and histone modifications are expensive. Moreover, antibody titers may vary from batch to batch. Ideally, if the antigen is in excess, the amount of antibodies used should be adjusted such that robust signal intensities are obtained compared to a mock control.

To give an example for a proper antibody titration, we performed ChIP using different dilutions of antibodies directed against the unmodified C-terminus of histone $\mathrm{H} 3$ and employed affinity-purified antibodies against vesicle-inducing protein in plastids 2 (VIPP2) as mock 

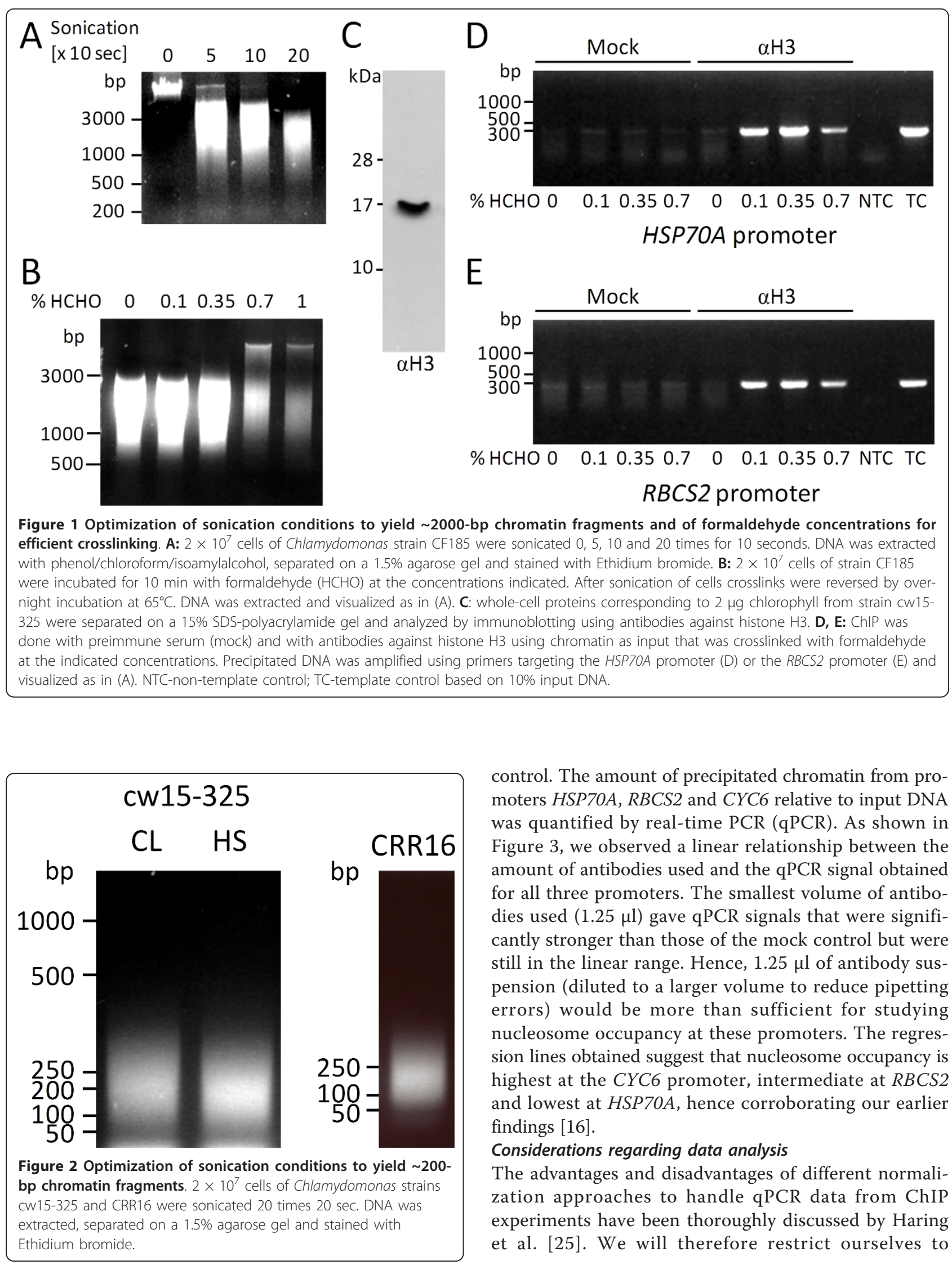

control. The amount of precipitated chromatin from promoters HSP7OA, RBCS2 and CYC6 relative to input DNA was quantified by real-time PCR (qPCR). As shown in Figure 3, we observed a linear relationship between the amount of antibodies used and the GPCR signal obtained for all three promoters. The smallest volume of antibodies used $(1.25 \mu \mathrm{l})$ gave qPCR signals that were significantly stronger than those of the mock control but were still in the linear range. Hence, $1.25 \mu \mathrm{l}$ of antibody suspension (diluted to a larger volume to reduce pipetting errors) would be more than sufficient for studying nucleosome occupancy at these promoters. The regression lines obtained suggest that nucleosome occupancy is highest at the CYC6 promoter, intermediate at $R B C S 2$ and lowest at HSP70A, hence corroborating our earlier findings [16].

\section{Considerations regarding data analysis}

The advantages and disadvantages of different normalization approaches to handle qPCR data from ChIP experiments have been thoroughly discussed by Haring et al. [25]. We will therefore restrict ourselves to 


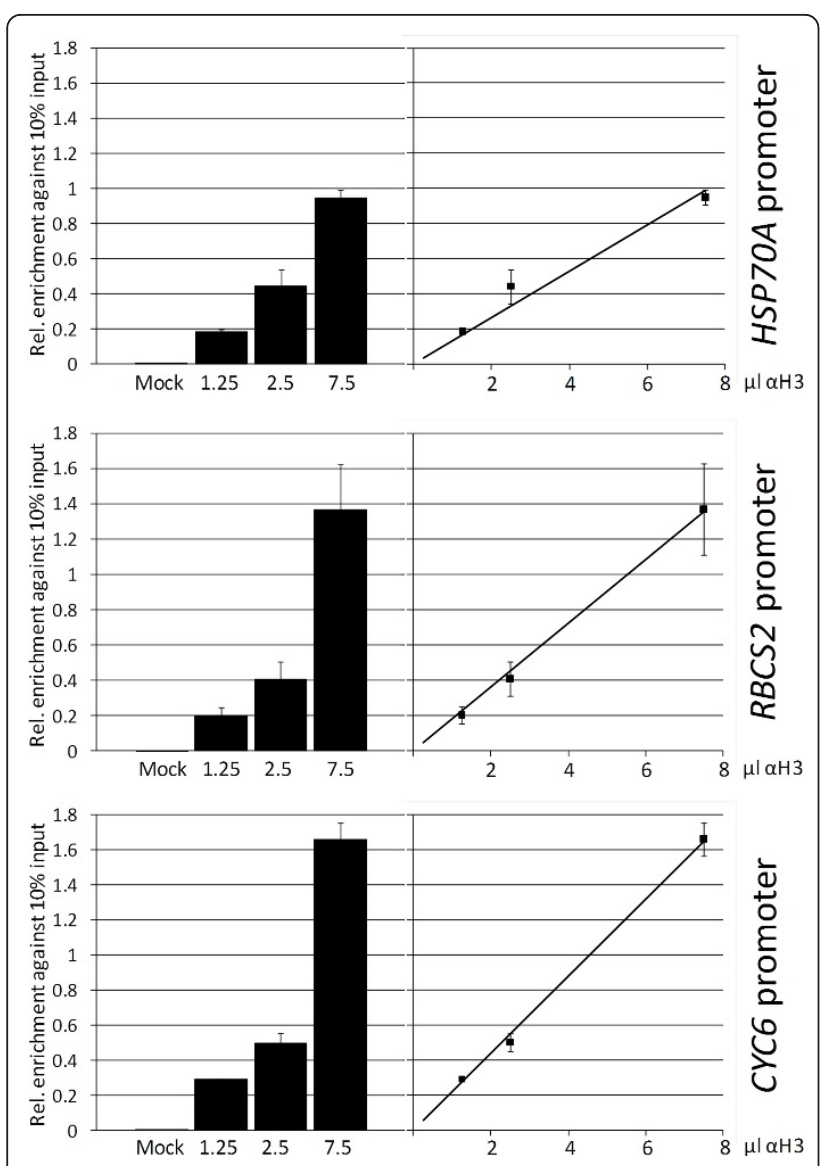

Figure 3 Testing for the linearity of ChIP efficiency with antibodies against histone H3. ChIP was done on $2 \times 10^{7}$ cells of Chlamydomonas strain CRR16 crosslinked with $0.35 \%$ formaldehyde. Cells were not subjected to stress. Chromatin was sonicated to fragments of $\sim 200$-bp and immunoprecipitated with affinity-purified antibodies against VIPP2 (mock) or with the indicated volumes of a suspension containing antibodies against histone $\mathrm{H} 3$. Precipitated DNA was amplified by qPCR using primers targeting promoters RBCS2, HSP70A, and CYC6. Shown are standard errors from 3 technical replicates. Values are normalized against those obtained with $10 \%$ input DNA.

describing how we do normalization and why [16].

1. No matter whether antibodies against core histones, histone modifications or transcription factors are used for ChIP, the qPCR signals from ChIPs using specific antibodies need to be significantly stronger than those from ChIPs using mock controls. Of course, the investigated antigen must be present at the target site investigated. The choice of a proper control antibody depends on the nature of the specific antibody used. For example, if the specific antibody is affinity-purified (like that against the C-terminus of histone H3), the control antibody-targeting an unrelated antigen-should be affinity-purified as well (like that against VIPP2).
2. Determine nucleosome occupancy and/or histone modifications at the locus of interest by normalizing qPCR signals from ChIPs with antibodies against a core histone and/or specific histone modifications with the qPCR signal from input chromatin (\%IP). This eliminates variations in PCR efficiency for the respective locus and makes comparisons between different loci (and different PCR runs) possible.

3. Express nucleosome occupancy and/or histone modifications determined for the locus of interest relative to that of a control locus known to contain nucleosomes and/or the histone modifications under investigation (note that when changes in nucleosome occupancy or histone modifications in response to e. g. a change in environmental conditions are monitored it is important to ensure that neither histone occupancy nor modifications are affected at the respective control locus). As values for target and control loci are obtained from the same ChIP experiment, technical variations within that experiment are eliminated. This procedure also allows integrating biological replicates where for example antibody batches with varying efficiencies were used. 4. As nucleosome occupancy may vary considerably between different loci (or even at the same locus in response to environmental cues), histone modifications generally need to be expressed relative to nucleosome occupancy.

When investigating histone modifications in Chlamydomonas, it is important to keep in mind that the amino acid sequences of Chlamydomonas histones are not entirely conserved with those of mammals, against which many commercially available antibodies for the detection of histone modifications are directed. For instance, Chlamydomonas histone H3 contains a threonine instead of a serine at position 28 and the alanine at position 29 found in mammalian histone $\mathrm{H} 3$ is deleted in the Chlamydomonas protein. As a consequence, commercially available antibodies against methyl-H3K27 are not functional in Chlamydomonas [8].

Heat stress leads to rapid nucleosome remodeling at the RBCS2 promoter

We have shown previously that heat stress caused reductions in levels of $\mathrm{H} 3$ and $\mathrm{H} 4$ acetylation at the Chlamydomonas RBCS2 promoter by $\sim 2$ - and $\sim 6$-fold, respectively, which correlated with a $\sim 20 \%$ increase in nucleosome occupancy [16]. Interestingly, this effect was not mediated by HSF1 and might be part of a global, heat shock-induced loss of histone acetylation that was first observed in Drosophila [33]. We could also show that HSF1-dependent remodeling of nucleosomes at the Chlamydomonas HSP22F promoter occurred within the first minute after onset of heat stress, right after binding 
of HSF1 to the promoter [16]. We wondered whether HSF1-independent remodeling of nucleosomes at the $R B C S 2$ promoter during heat stress occurred as fast as HSF1-dependent remodelling at HSP22F. To address this question, we employed ChIP to monitor nucleosome occupancy and levels of $\mathrm{H} 3$ and $\mathrm{H} 4$ acetylation at the $R B C S 2$ promoter during the first $10 \mathrm{~min}$ of heat stress.

For the evaluation of this experiment we followed the normalization guidelines given above: (1) qPCR signals from precipitates generated with specific antibodies were much stronger than those obtained from precipitates generated with mock antibodies (not shown). (2) qPCR signals obtained with antibodies against histone $\mathrm{H} 3$, di-acetylated $\mathrm{H} 3$ and tetra-acetylated $\mathrm{H} 4$ were first normalized to those gained with $10 \%$ input DNA and (3) subsequently normalized to the respective values obtained for the CYC6 control promoter (nucleosome occupancy and levels of $\mathrm{H} 3 / \mathrm{H} 4$ acetylation at the CYC6 promoter were shown not to change during heat stress [16]). (4) qPCR signals obtained with antibodies against acetylated histones were expressed relative to those obtained with antibodies against unmodified histone H3.

As shown in Figure 4, a significant decrease in levels of histone $\mathrm{H} 4$ acetylation at the $R B C S 2$ promoter was observed 2 min after onset of heat stress. Trends towards reduced levels of $\mathrm{H} 3$ acetylation and increased histone occupancy were also discernible after about 2 min of heat stress. Hence, HSF1-independent nucleosome remodeling at the $R B C S 2$ promoter after heat stress is fast (within $2 \mathrm{~min}$ ), but not as fast as HSF1dependent nucleosome remodeling at the HSP $22 F$ promoter (within $1 \mathrm{~min}$ ).

\section{Conclusions}

We describe here a detailed chromatin immunoprecipitation protocol for Chlamydomonas. We demonstrate the optimization of the most important parameters, which are the crosslinking conditions, the shearing of chromatin, the titration of antibodies and the normalization of results obtained by qPCR. Compared to earlier ChIP protocols described for Chlamydomonas [5,6,9], our protocol bears the following improvements: (i) it combines cell lysis and chromatin fragmentation in a single step. (ii) It facilitates high-resolution analyses as chromatin is fragmented into mononucleosomes rather than tri- to pentanucleosomes. (iii) It allows precipitating transcription factors and associated DNA [16]. By demonstrating that after heat shock histone acetylation levels at the RBCS 2 promoter rapidly decrease and

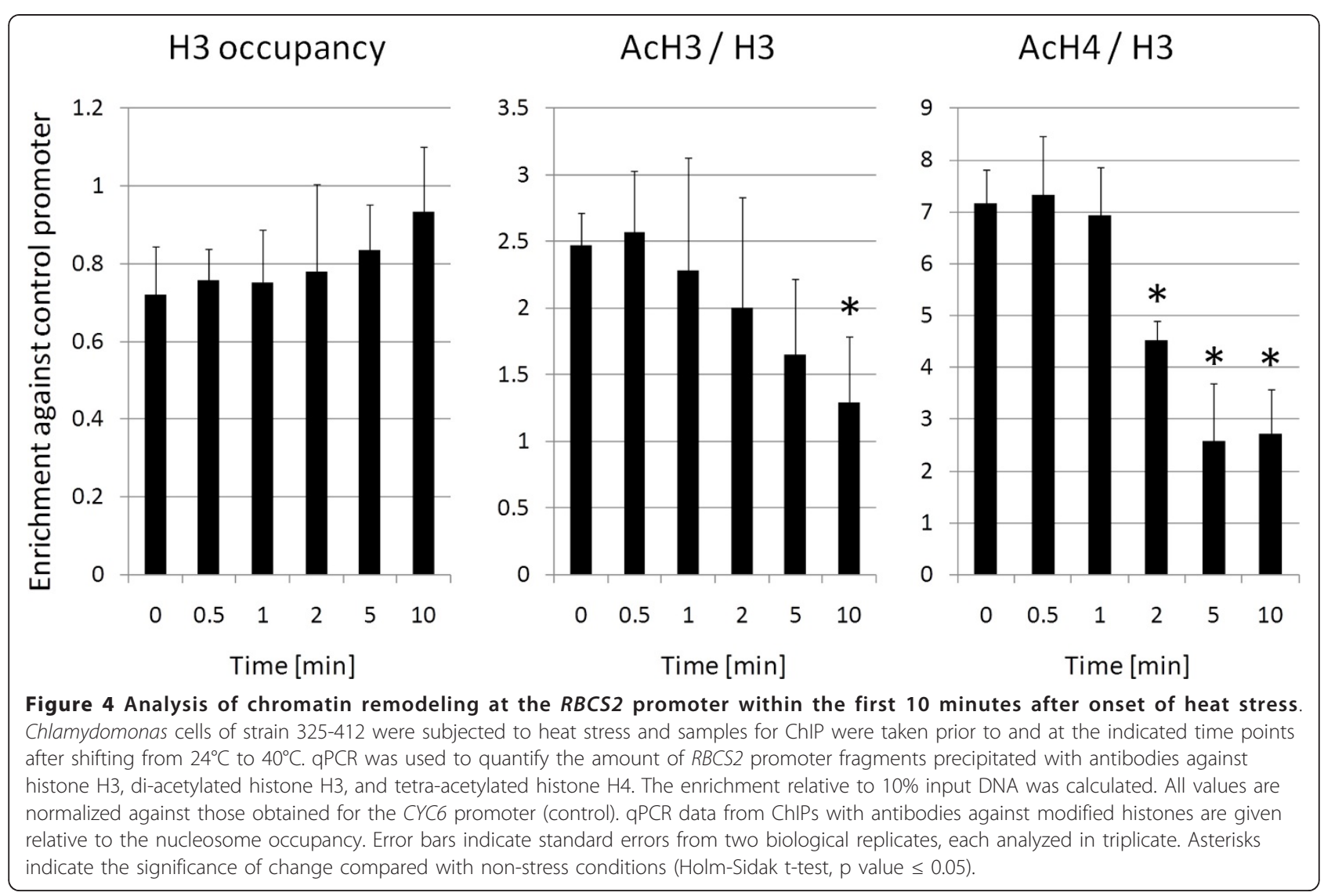


nucleosome occupancy rapidly increases we provide an example for the suitability of our ChIP protocol for monitoring changes of chromatin structure in a minutes scale. Our protocol will prove useful for targeted and genome-wide studies of chromatin structure in Chlamydomonas and other eukaryotic microalgae.

\section{Acknowledgements}

We thank Stephen M. Miller (University of Maryland, Baltimore, MD) for stimulating discussions. This work was supported by the Max Planck Society and grants from the Deutsche Forschungsgemeinschaft (Schr 617/4-3) and the Bundesministerium für Bildung und Forschung (Systems Biology Initiative FORSYS, project GOFORSYS).

\section{Authors' contributions}

DS participated in the design of the study, carried out all experiments and drafted the manuscript. SS participated in the design of the study and helped with data evaluation. MS conceived and coordinated the study, and wrote the manuscript. All authors read and approved the final manuscript.

\section{Competing interests}

The authors declare that they have no competing interests.

Received: 13 July 2011 Accepted: 3 November 2011

Published: 3 November 2011

\section{References}

1. Harris EH: The Chlamydomonas Sourcebook: Introduction to Chlamydomonas and Its Laboratory Use. 2 edition. San Diego, CA: Elsevier/Academic Press; 2008.

2. Merchant SS, Prochnik SE, Vallon O, Harris EH, Karpowicz SJ, Witman GB, Terry A, Salamov A, Fritz-Laylin LK, Marechal-Drouard L, et al: The Chlamydomonas genome reveals the evolution of key animal and plant functions. Science 2007, 318:245-250.

3. Cerutti $H$, Johnson AM, Gillham NW, Boynton JE: Epigenetic silencing of a foreign gene in nuclear transformants of Chlamydomonas. Plant Cell 1997, 9:925-945.

4. Zhang C, Wu-Scharf D, Jeong BR, Cerutti H: A WD40-repeat containing protein, similar to a fungal co-repressor, is required for transcriptional gene silencing in Chlamydomonas. Plant J 2002, 31:25-36.

5. van Dijk K, Marley KE, Jeong BR, Xu J, Hesson J, Cerny RL, Waterborg JH, Cerutti $\mathrm{H}$ : Monomethyl histone $\mathrm{H} 3$ lysine 4 as an epigenetic mark for silenced euchromatin in Chlamydomonas. Plant Cell 2005, 17:2439-2453.

6. Casas-Mollano JA, van Dijk K, Eisenhart J, Cerutti H: SET3p monomethylates histone $\mathrm{H} 3$ on lysine 9 and is required for the silencing of tandemly repeated transgenes in Chlamydomonas. Nucleic Acids Res 2007, 35:939-950.

7. Casas-Mollano JA, Jeong BR, Xu J, Moriyama H, Cerutti H: The MUT9p kinase phosphorylates histone $\mathrm{H} 3$ threonine 3 and is necessary for heritable epigenetic silencing in Chlamydomonas. Proc Natl Acad Sci USA 2008, 105:6486-6491.

8. Shaver S, Casas-Mollano JA, Cerny RL, Cerutti H: Origin of the polycomb repressive complex 2 and gene silencing by an $E(z)$ homolog in the unicellular alga Chlamydomonas. Epigenetics 2010, 5:301-312.

9. Yamasaki T, Miyasaka H, Ohama T: Unstable RNAi effects through epigenetic silencing of an inverted repeat transgene in Chlamydomonas reinhardtii. Genetics 2008, 180:1927-1944.

10. Yamasaki T, Ohama $\mathrm{T}$ : Involvement of Elongin $C$ in the spread of repressive histone modifications. Plant J 2011, 65:51-61.

11. Kropat J, Tottey S, Birkenbihl RP, Depège N, Huijser P, Merchant S: A regulator of nutritional copper signaling in Chlamydomonas is an SBP domain protein that recognizes the GTAC core of copper response element. Proc Natl Acad Sci USA 2005, 102:18730-18735.

12. Wykoff DD, Grossman AR, Weeks DP, Usuda H, Shimogawara K: Psr1, a nuclear localized protein that regulates phosphorus metabolism in Chlamydomonas. Proc Natl Acad Sci USA 1999, 96:15336-15341.
13. Xiang Y, Zhang J, Weeks DP: The Cia5 gene controls formation of the carbon concentrating mechanism in Chlamydomonas reinhardtii. Proc Natl Acad Sci USA 2001, 98:5341-5346.

14. Fukuzawa H, Miura K, Ishizaki K, Kucho Kl, Saito T, Kohinata T, Ohyama K: $\mathrm{Ccm} 1$, a regulatory gene controlling the induction of a carbonconcentrating mechanism in Chlamydomonas reinhardtii by sensing $\mathrm{CO}_{2}$ availability. Proc Natl Acad Sci USA 2001, 98:5347-5352.

15. Schulz-Raffelt M, Lodha M, Schroda M: Heat shock factor 1 is a key regulator of the stress response in Chlamydomonas. Plant J 2007, 52:286-295.

16. Strenkert D, Schmollinger S, Sommer F, Schulz-Raffelt M, Schroda M: Transcription factor dependent chromatin remodeling at heat shock and copper responsive promoters in Chlamydomonas reinhardtii. Plant Cell 2011, 23:2285-2301.

17. Solomon MJ, Larsen PL, Varshavsky A: Mapping protein-DNA interactions in vivo with formaldehyde: evidence that histone $\mathrm{H} 4$ is retained on a highly transcribed gene. Cell 1988, 53:937-947.

18. Pokholok DK, Harbison CT, Levine S, Cole M, Hannett NM, Lee TI, Bell GW, Walker K, Rolfe PA, Herbolsheimer E, et al: Genome-wide map of nucleosome acetylation and methylation in yeast. Cell 2005, 122:517-527.

19. Guertin MJ, Lis JT: Chromatin landscape dictates HSF binding to target DNA elements. PLOS Genet 6.

20. Dedon PC, Soults JA, Allis CD, Gorovsky MA: A simplified formaldehyde fixation and immunoprecipitation technique for studying protein-DNA interactions. Anal Biochem 1991, 197:83-90.

21. Orlando V, Strutt $H$, Paro R: Analysis of chromatin structure by in vivo formaldehyde cross-linking. Methods 1997, 11:205-214.

22. Hecht A, Grunstein M: Mapping DNA interaction sites of chromosomal proteins using immunoprecipitation and polymerase chain reaction. Methods Enzymol 1999, 304:399-414.

23. Das PM, Ramachandran K, van Wert J, Singal R: Chromatin immunoprecipitation assay. Biotechniques 2004, 37:961-969.

24. Bowler C, Benvenuto G, Laflamme P, Molino D, Probst AV, Tariq M, Paszkowski J: Chromatin techniques for plant cells. Plant J 2004, 39:776-789.

25. Haring M, Offermann S, Danker T, Horst I, Peterhansel C, Stam M: Chromatin immunoprecipitation: optimization, quantitative analysis and data normalization. Plant Methods 2007, 3:11.

26. Ricardi MM, Gonzalez RM, lusem ND: Protocol: fine-tuning of a Chromatin Immunoprecipitation (ChIP) protocol in tomato. Plant Methods 2010, 6:11.

27. Casas-Mollano JA, Rohr J, Kim EJ, Balassa E, van Dijk K, Cerutti H: Diversification of the core RNA interference machinery in Chlamydomonas reinhardtii and the role of DCL1 in transposon silencing. Genetics 2008, 179:69-81.

28. Schroda M, Vallon O, Wollman FA, Beck CF: A chloroplast-targeted heat shock protein 70 (HSP70) contributes to the photoprotection and repair of photosystem II during and after photoinhibition. Plant Cell 1999, 11:1165-1178.

29. Willmund F, Schroda M: HEAT SHOCK PROTEIN $90 \mathrm{C}$ is a bona fide Hsp90 that interacts with plastidic HSP70B in Chlamydomonas reinhardtii. Plant Physiol 2005, 138:2310-2322.

30. Mitchell $B L$, Yasui $Y$, Li Cl, Fitzpatrick AL, Lampe PD: Impact of freeze-thaw cycles and storage time on plasma samples used in mass spectrometry based biomarker discovery projects. Cancer Inform 2005, 1:98-104.

31. Chua YL, Brown AP, Gray JC: Targeted histone acetylation and altered nuclease accessibility over short regions of the pea plastocyanin gene. Plant Cell 2001, 13:599-612.

32. Lodha M, Schroda M: Analysis of chromatin structure in the control regions of the Chlamydomonas HSP7OA and RBCS2 genes. Plant Mol Biol 2005, 59:501-513.

33. Arrigo P: Acetylation and methylation patterns of core histones are modified after heat or arsenite treatment of Drosophila tissue culture cells. Nucleic Acids Res 1983, 11:1389-1404.

doi:10.1186/1746-4811-7-35

Cite this article as: Strenkert et al:: Protocol: methodology for chromatin immunoprecipitation (ChIP) in Chlamydomonas reinhardtii. Plant Methods 2011 7:35. 